\title{
The accounting curriculum and the emergence of Big Data
}

\author{
Khadija Dewu a and Yasser Barghathi ${ }^{\mathrm{a}, 1}$ \\ Edinburgh Business School, Heriot-Watt University Dubai
}

\begin{abstract}
Research Question: Is there a gap between the accounting curriculum and its practice in this era where Big Data analytics is potentially a vital part of accounting? Motivation: The emergence of Big Data has instigated modifications in the professional accounting world. Collecting and analysing Big Data has become a part accounting as it is beneficial. The role of university curriculums is to prepare students for the practice, so it is expected to evolve along with the profession. However, Big Data analytical skills are not included in the accounting curriculum in universities which has resulted in graduates being incompetent at workplaces because the skills they possess are obsolete. Idea: The purpose of this study is to explore the extent to which the accounting curriculum is capable of equipping students with the necessary competencies to become accounting practitioners with the emergence of Big Data in the profession. It seeks to discover the level information asymmetry between the accounting curriculum and the practice. Data: 15 Interviews were conducted with accounting professors and practitioners in a bid to discover the competencies needed and what the potentially curriculum lacks. Additionally, document analysis was also used to examine learning materials provided to accounting students in form of lecture notes, coursework and examinations to support claims made by professors. Tools: interviews and content analysis were used to collect research data. Findings: It was found that the accounting curriculum is lacking adequate knowledge to equip students with the competencies to handle Big Data Analytics and has restricted accounting graduates' capabilities. Contribution: Based on the findings, a framework has been developed which contains the necessary competencies accounting students should possess in order to be able to handle Big Data analytics. The results of this study will potentially be of interest to several stakeholders including accounting academics and professionals.
\end{abstract}

Keywords: Big Data, analytics, competencies, curriculum, skills, techniques

1 Corresponding author: Yasser Barghathi, Edinburgh Business School, Heriot-Watt University Dubai, International Academic City Dubai. E: y.barghathi@hw.ac.uk. 


\section{JEL codes: M41}

\section{Introduction}

Over the past 30 years there have been significant modifications in the accounting profession (Hay, 2010). The changes resulted from multiple factors with technological advancement and the employment of information technology in the practice being the most prominent (Mohamed \& Lashsine, 2003).

The $21^{\text {st }}$ century is known as the Information age due to its dependence on data. In the early 2000's, advancement in information technology (IT) escalated which resulted in rapid creation of data that resulted in easy access to information and research opportunities (Beattie \& Pratt, 2003). Technological advancement has given rise to more ways of transmitting information through sophisticated devices such as mobile phones, computers and smart devices. It has established a digital era whereby the use of sophisticated computers and software have led to an overflow of data. Every day, approximately 2.5 quintillion bytes of data is created (Taylor-Sakyi, 2016). This vastness of information prompted an explosion of data which led to the emergence of Big Data (BD) (Beattie \& Pratt, 2003). Big Data can be defined as substantial amount of structured and unstructured data that cannot be analysed using conventional data analysis methods. It has four dimensions; volume, velocity, veracity and variety (Janvrin \& Watson, 2017).

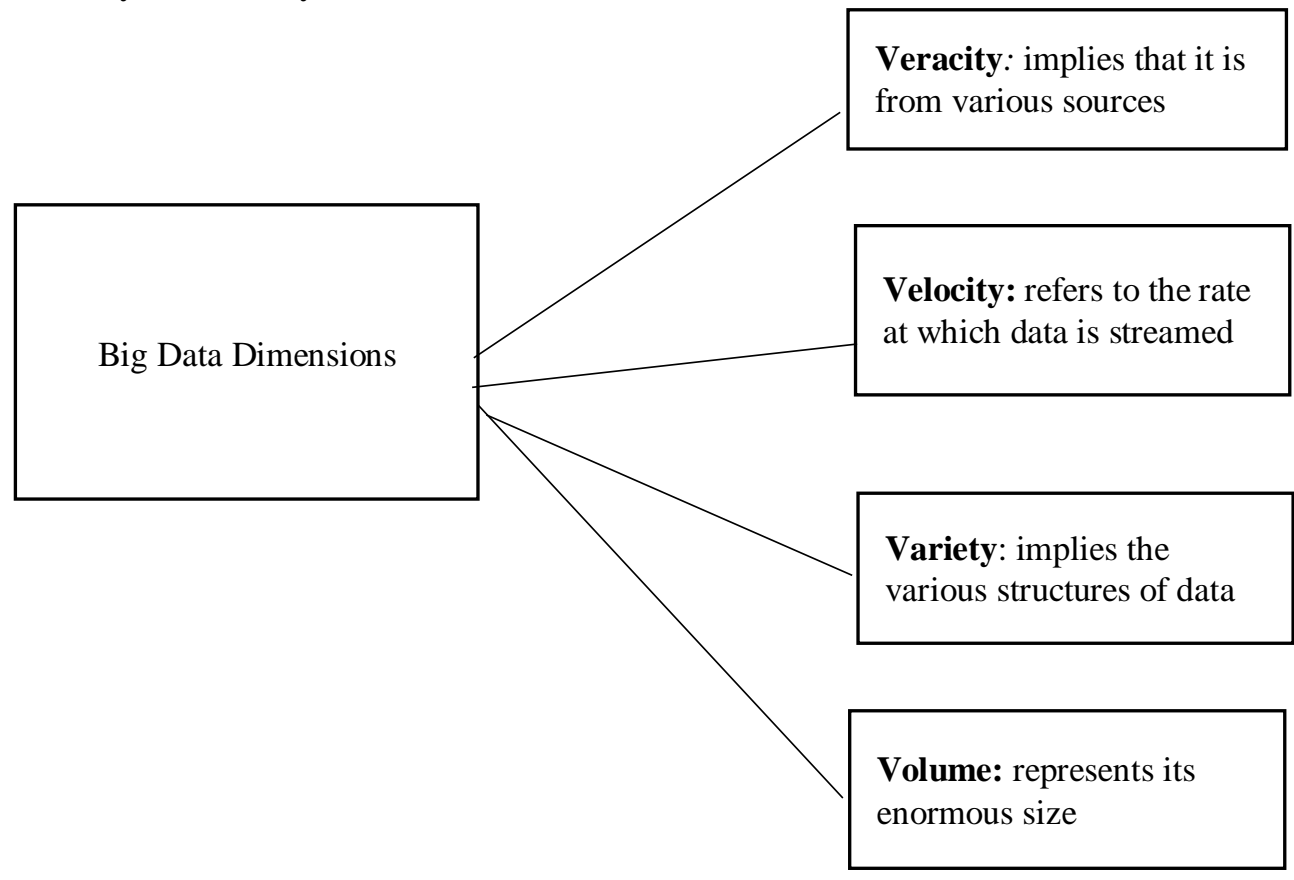

Figure 1. Dimensions of Big Data 
In the early 2000's, organizations began to manipulate this data to gain more information. Developments in the internet provided easy access to information and research opportunities which enables researchers to find more specific data (Beattie and Pratt, 2003). Big Data however is too large for conventional analytical methods to handle (Taylor-Sakyi, 2016). This gave rise to a concept known as Big Data Analytics (BDA). The use of Big Data is prominent in accounting nowadays. According to ACCA (2011) it is expected to significantly affect accounting standards by 2024 . This will be necessary to prevent accounting standards from being obsolete because the present standards were created in the era of slow data collection speed and high cost of transmission. This makes Big Data analytical skills a core competency in the accounting profession.

The purpose of this study is to explore the extent to which the accounting curriculum is capable of equipping students with the necessary competencies to become accounting practitioners with the emergence of Big Data in the profession. It seeks to discover the level information asymmetry between the accounting curriculum and the practice. Furthermore, it will identify the BDA competencies that accounting graduates should be equipped with to be able to handle Big Data. This will be achieved by investigating the modifications BDA has brought to accounting and comparing it to the present accounting curriculum offered to students. Lawson et al. (2014) accounting framework and Chapman's Generic Competency model will be used to highlight competencies and interpersonal skills required in the modern accounting profession in general.

The emergence of Big Data has instigated modifications in the professional accounting world. Collecting and analysing Big Data has become a part accounting as it is beneficial. The role of university curriculums is to prepare students for the practice, so it is expected to evolve along with the profession. However, Big Data analytical skills are not included in the accounting curriculum in universities which has resulted in graduates being incompetent at workplaces because the skills they possess are obsolete (McKinney, 2017). Failure to include BDA in the curriculum will lead to a continuous array of accounting students that are unable to handle Big Data which is a seemingly crucial part of every profession nowadays.

The aim of this research is to explore the extent to which the accounting curriculum prepares accounting students for a career in accounting with the recent employment of Big Data Analytics in the practice. It seeks to examine whether there is a gap between the curriculum and the profession due to this and competencies needed to bridge the gap. The research tried to provide answers to the following research questions:

RQ1: How has Big Data affected accounting?

RQ2: Is there a need to include Big Data Analytics in the accounting curriculum in universities?

RQ3: What are the skills and techniques needed by accounting graduates to handle Big Data?

RQ4: Are accounting graduates' competent enough to handle Big Data? 
The importance of this research is to discover how to bridge the possible gap between the accounting curriculum and the practice. It will explore the impact of Big Data in accounting and the BDA skills and techniques used in accounting practices. This will aid in discovering the appropriate curriculum that will help produce competent accounting graduates.

The researcher being an accounting student assumes that there vast is a gap between the accounting curriculum and the practice with regards to Big Data knowledge, skills and techniques. Universities focus more on the theoretical aspect of accounting which seems to become more obsolete the more the world advances. Despite providing minimal practical, university curriculums do not focus on enriching students' interpersonal skills which are highly required by all professions nowadays. The paper is structured as follows: Section 1 introduces the research topic. It provides background information about the topic and presents the research aims, objectives and questions. It also provides a brief introduction of the concept of Big Data. While Section 2 contains the literature review based on past studies which expands on the significance of Big Data Analytics and its use in various aspects accounting. It provides a detailed explanation of what Big Data is, its characteristics and significance in establishments. Furthermore, a brief discussion of the situation of the accounting curriculum is provided and the 2 frameworks to be used in this research are introduced. Section 3 includes a discussion of research methodology, data collection and analysis methods employed for this research and justifications for choosing them. Additionally, it discusses the limitations encountered while carrying out fieldwork. Section 4 contains the findings from the fieldwork carried out that were absent in the literature. And finally, Section 5 that contains the conclusive analysis, future recommendations and contributions of this research.

\section{Literature review}

This Literature review provides an overview of how Big Data Analytics is used in accounting. The findings show the techniques, skills and software employed to gain insight from data for decision making. It describes how BDA is incorporated in various aspects of accounting such as forensic accounting, auditing, managerial accounting, taxation and financial accounting. It further discusses the 2 competency frameworks to be used for this research.

\subsection{Big Data Analytics}

According to Bhimani and Willcocks (2014) utitlising data is valuable, however data in its raw form is useless and cannot provide insight unless it is tortured enough. Chen et al (2012) define Big Data Analytics (BDA) as "a new generation of technologies and architectures, designed to economically extract value from very large volumes of a wide variety of data, by enabling high velocity capture, discovery and/or analysis". It includes identifying, extracting, processing, storing and 
evaluating data to transform it into useful information using advanced techniques and software (Alsghaier et al., 2017). Data is retrieved in various forms from multiple sources as shown in Table 1. Structured data is data in simple forms that can easily be used and stored in databases while unstructured data is in forms such as emails, audios, videos and social media posts.

Table 1: Sources and forms of Data

\begin{tabular}{ll}
\hline \multicolumn{1}{c}{ Source } & \multicolumn{1}{c}{ Forms } \\
\hline Media & Emails, Images, texts, videos, audios from \\
& social media platforms such as twitter, \\
& Instagram and Facebook. \\
Web & Data found on websites \\
Internet of Things & Data gotten from sensors from interrelated \\
& devices such as computer devices, video \\
& games appliances and that can exchange \\
& data using a network. These include health \\
& monitors, car trackers, smart home products \\
& and satellites. \\
& Public, private and third-party clouds such \\
Cloud & as iCloud, one drive and Egnyte. \\
& Traditional and modern databases such as \\
Databases & Informix, SQL server and oracle database. \\
\hline
\end{tabular}

It used by leading companies such as Google, Microsoft, Yahoo, Amazon, Ebay and more (Chen et al., 2012). The use of Big Data is essential in accounting today which makes Big data analytical skills a core competency for a job in the field. According to the ACCA (2019) big data is now valued as an asset by $20 \%$ of large companies and is found in their balance sheets.

\subsubsection{Techniques}

BDA involves quantitative analysis, development testing, training, scoring and monitoring models (Borodo et al., 2016). Various techniques such as data mining, semantic analytics, data visualization, geospatial analysis and data discovery are used to gain insight from extracted data. For instance, data visualization involves the use of infographics and statistics to explain ideas (Braganza et al., 2017). Additionally, text mining and semantics are used to analyse data in form of text such as documents, emails, tweets, and transactions.

More advanced techniques include pattern recognition, natural language processing, genetic algorithms, A/B testing association, association ruling and artificial intelligence such as decision trees and machine learning (Braganza et al., 2017).

Machine learning for instance, is used to analyse data by creating patterns and making decisions with little to no human interaction (Figure 2). Neural networks are 
the most popular machine learning techniques. They imitate the human brain system and have the capacity to scan images, recognize and classify them. Techniques can be mixed to achieve better results (Borodo et al., 2016).

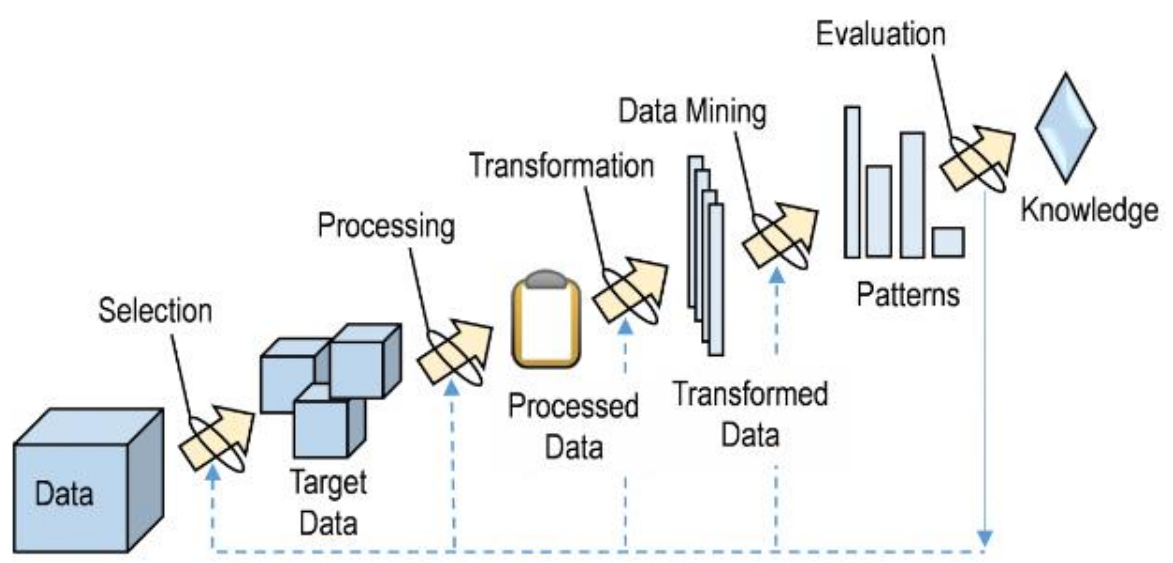

Figure 2: Pattern recognition, a machine learning technique (Source: APA)

\subsubsection{Software}

BDA involves the use of software such as Hadoop, NoSQL, Spark, Map Reduce, tableau for data visualization, GoogleAnalytics, MapReduce (Borodo et al., 2016). Hadoop for instance is a system which allows for Big Data Analysis by forming queries. Figure 3 below shows how Hadoop analyses data. Software can be used along with techniques to provide insight (Kleckner et al., 2015)

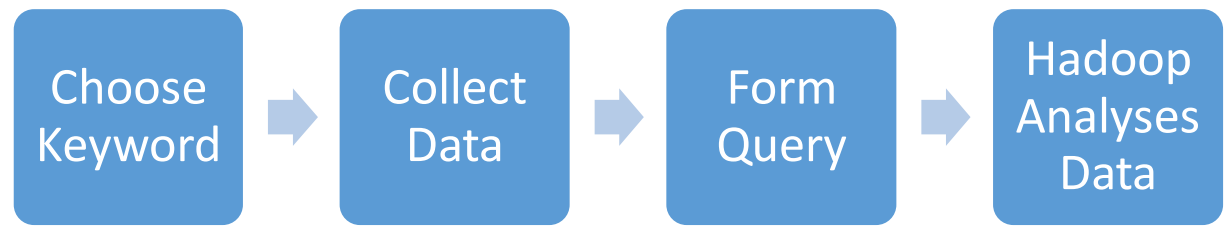

Figure 3: Big Data Analysis using Hadoop

\subsubsection{Types of analytics}

Data can be analysed using predictive, prescriptive, descriptive or diagnostic analytics. Predictive analysis is the most popular form of analytics. It is used to predict future trends and patterns using past trends and historical data (Braganza et al., 2017). Prediction can be used to foresee the risks of long-term investments. It 
can also be used to predict customer behavior. For example, a company can predict the outcome of increasing prices of products or services based on its customers spending habits (Kleckner et al., 2015).

Prescriptive analytics is used to find a solution to a problem or take advantage of an opportunity. It is used in discovering the best possible action to take to handle a specific issue. For instance, customer analytics can be used to discover customers' preferences so as to take advantage of them. This type of analytics requires both historical and external data (Kleckner et al., 2015).

Descriptive analytics involves using trends to explain past events. It provides information on whether something is right or wrong but does not provide a reason why or how an event happened. Association ruling for instance can be used in descriptive analytics as it shows the probability of an event happening. For example, if a customer buys butter, he is probably going to buy bread (Borodo et al., 2016).

Diagnostic analytics is conducted to find the significance of an event. It tries to link an event and its possible cause. Additionally, it is used to identify patterns and the insight derived from it is in depth. For instance, a company can conduct diagnostic analysis to customers' data to find the segment with the highest sales and the reason for that (Kleckner et al., 2015).

These various techniques can also be used together. For instance, predictive analysis can be done based on findings from diagnostic and descriptive analysis. The accuracy of these analytics depends on the size of sample used (Borodo et al., 2016).

\subsection{Significance of Big data in Accounting}

BDA is a significant decision-making component in companies. How it is used to make decisions in various branches of accounting will be described here.

\subsubsection{Auditing}

According to American Institute of Certified Public Accountants (AICPA), if auditing were introduced today, the use of information technology would be a prominent part of its processes. Prominent Audit firms such as KPMG have been using Big Data in their processes since 2014 (Wamba, 2017).

BDA is used for identifying potentially fraudulent activities, applying safeguards and security purposes. Additionally, because data sources are trust worthy and from primary sources, suspicious activities and red flags can be detected easily (Janvrin \& Watson, 2017). For instance, auditors can use BDA to monitor suspicious transactions such as money laundering by analyzing cash transactions. Based on this, payments that supersede a certain amount will require special attention. Big data can complement traditional audit evidence to improve the quality and authenticity 
of audit activities. For instance, phone call records and emails can be used to verify sales and orders. Social media analysis can be used for feedback on products, reputational risks, and many other forms of customer analytics (Janvrin \& Watson, 2017).

Predictive analytics can be used to in financial statement audit to project future expectations hence it can be used to determine whether a company is a going concern or not. Furthermore, BDA can also be used for designing controls measures and risk assessment (Enget et al., 2017).

\subsubsection{Management Accounting}

Big Data Analytics' most prominent use in management accounting is to enhance decision making and gain competitive advantage. The most efficient way to do this is by utilizing customer analytics. Based on previous literature there is a positive correlation between using customer analytics and the performance of a firm as it provides insights on customers views and how to retain them (Vasarhelyi, 2015). This aids in recognising trends and creating opportunities for companies which can be used to improve marketing skills and targeting (Vasarhelyi, 2015). For instance, Amazon uses Big Data Analytics to personalize recommendations to customers and $35 \%$ of sales come from these personalised recommendations (Enget, 2017).

Most companies that utilize Big Data notice an improvement in financial performance and widely outperform companies in similar industries. According to Lui (2014) BDA is used to differentiate between high and low performing companies. McKinsey's conducted a study on 330 public companies and discovered that companies that utilize BDA more productive and profitable than companies who do not (McKinsey, 2011). Furthermore, it improves operational efficiency as it can be used to predict outcomes, which is useful to budgeting and risk forecasting (Janvrin \& Watson, 2017). It aids in strategic planning, cost management and risk management through data perspective which leads to efficiency in operations. Additionally, it aids in maximizing profit as it is used for assessing the key performance indicators of a company (Collins, 2012).

Insights from customer analytics can be used to handle business risk. Through social media analysis for instance, information about product complaints can be used to improve models. Also, sales can be predicted based on the number of people on social media that are interested in a certain product or service (Warren et al 2015). It can also be used for creating strategies. For instance, the age group of consumers can be predicted based on purchasing habits. This can enable a company to know their target market (Vasarhelyi, 2015).

Predictive analytics can be used to resolve, "what if" situations. For instance, with inventory, analysed data can predict demand trends which is used to match inventory to the demands (Warren et al., 2015). 


\subsubsection{Forensic Accounting}

In 2014, a survey carried out by the Forensic and Valuation Services Section of American Institute for Certified Public Accountants, it was discovered that Big Data is a lucrative aspect of forensic accounting (Gamage, 2016). Characteristics of big data such as reliability, accuracy, consistency and easy access are pivotal to forensic accounting practices. According to Rezaee (2017) study 80\% of Chinese practitioners have noticed that Big Data Analytics has improved their forensic accounting practices.

Data can be retrieved from GPS, radio frequency identification, automated sensors and transaction records which can speed up processes in forensic accounting. Additionally, various emails, social media, expense history and payment descriptions are available to inspect (Rezaee, 2017). Furthermore, BDA can be used to detect risky activities and suspicious transactions. For instance, predictive analytics can be used by accounting institutions for fraud analysis. Addresses and fake identities can be discovered using resolution algorithms and credit cards can be tracked using analytics to manage line of credit (Sledgianowski, 2017). Techniques such as social media analysis, behavior analysis, data and geospatial analysis can be employed for tracking (Borodo et al., 2016).

\subsubsection{Financial accounting}

In financial accounting, Big Data Analytics aid in detecting errors and misstatements in financial reports (Rezaee, 2017). This leads to provision of accurate and reliable information which improves decision making. The USA Security and exchange commission use a BDA tool called RobotCop to figure out irregularities in financial statements, violations of security law and issues in auditing (Rezaee, 2017). Additionally, it is used for financial modelling to create more refined standards that go along with the economy and stock market predictions. (Warren et al., 2015). It simplifies the work of financial analytics by making it easier to gauge risks.

Technological developments that give users access to data have brought about a change in corporate reporting mainly because reporting has been moved to cloud platforms. An example of this is the SoMoClo which stands for Social, Mobile and Cloud. Using this, a corporation's data and applications are within a central system where users can easily access them. These developments have made it possible for companies and their stakeholders to access various forms of data to analyse (Janvrin \& Watson, 2017).

\subsubsection{Taxation}

The use of Big Data in Taxation is limited. Technology in taxation is mostly used for tax research on tax law sources and codes and tax preparation using software (Gammage, 2016). However, organisations produce large amount of tax data which is beneficial as it can be used to gain insights. The application of BD in taxation has 
eased the efforts required for high levels of accuracy and has increased the use of tax information in accounting. It can be used for calculation of indirect tax and tax codes. Additionally, predictive analysis can be used to analyze tax data that would normally require more effort (Sledgianowski, 2017).

According to The New York Department of Taxation and Finance, using Big Data for predictive analysis altered its fraud recognition and detection system to detect income tax return fraud. It does this by using statistical software and pivot tables to analyse tax data. The role of tax accountants itself is changing because of BD as they are now also involved analysis unlike when they did strictly tax work (Gammage, 2016).

\subsection{The accounting curriculum}

A study in New Zealand involving accounting employees, graduates in professors tested the competencies and effectiveness of teachings based on the accounting curriculum and it was discovered that students lack core skills and techniques because they are solely taught intellectual knowledge (Bui \& Porter, 2010). Similar studies such as Quek (2005), Bolt-Lee and Foster (2014) and Hakim (2016) have been conducted and the same results were yielded. Multiple frameworks have been developed based on these competencies that accounting graduates seem to lack. Two important frameworks include Lawson et al. (2014) accounting competency framework and Chapman and Young (2010) generic competency model.

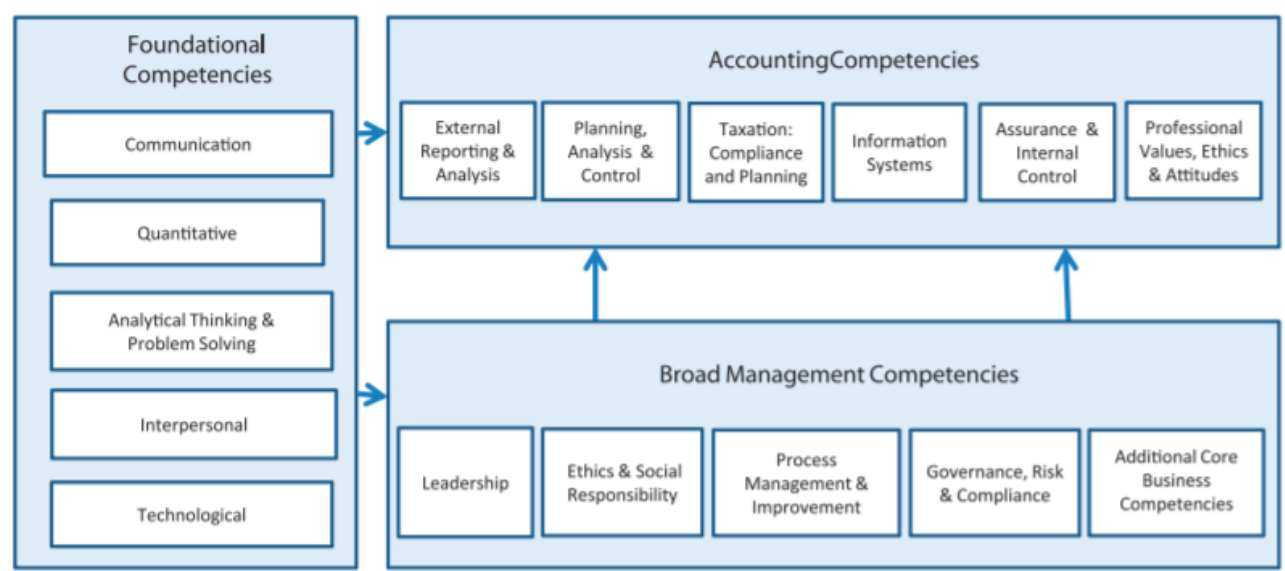

Figure 4: Lawson et al framework for accounting education (Lawson et al., 2014: 300)

The Lawson et al. (2014) framework (Figure 4) states that accounting students should be equipped with foundational, accounting and broad management competencies. The foundational competencies consist of quantitative and technological competencies and analytical and problem solving which are key BDA competencies.

According to Chapman and Young (2010) model of generic competencies, students should possess the following skills and techniques prior entering the corporate world; Teamwork, problem-solving, effective communication, technological skills, 
planning and organizing, self-management, learning skills Initiative and enterprise. These soft skills are necessary for efficient decision making using analysed data (Mohamed \& Lashine, 2003).

\subsection{Challenges of Big Data Analytics}

Threats that arise with utilizing Big Data entail privacy, security, storage and processing issues. Analyzing individuals' publicly available data exposes personal information which might lead to invasion of privacy (Borodo et al., 2016). Additionally, legal policies can be imposed to protect individuals' data which restricts data collection and analysis (Rezaee, 2017). Additionally, certain software such as Map Reduce need to be equipped with high security because they are easy to hack into so Individuals information might be at risk. Data storage is also challenge as some data sets are too large and require strong network and servers that will be able to process and store the data (Borodo et al., 2016).

\section{Methodology and research methods}

This study is exploratory in nature as its aim is to answer why, when and how with regards the assumed impact of Big Data in accounting practice and its effect on the accounting curriculum so the suitable philosophy to be used is Interpretivism (Castellan, 2010).

This study included a multiple case study because it involves studying two sets of people which are the practitioners and the professors. A multiple case study is suitable when studying two or more contrasting phenomena to highlight a gap or to show similarity in results (Yin, 1984). This will enable the study to gain extensive details of the similarities and differences between the perspectives of practitioners and professors with regards to $\mathrm{BD}$. The gap, if any lies between the differences (Avery et al., 2011).

The data collection methods used for this research include interviews and document analysis. The Interview procedure included oral and online interviews. Skills and knowledge required for BDA based on literature alongside Lawson et al and Chapman's framework were used to create interview questions. Accounting professors were interviewed on their views on BDA and the accounting curriculum. Additionally, their views on the competency of their accounting students were discussed. Accounting practitioners were interviewed on the integration of BDA in the accounting profession and the competency of accounting graduates. The interviews were conducted to two sets of individuals; accounting professors and accounting practitioners. The sample used for the interviews conducted include 5 accounting professors and 10 accounting practitioners. This is because if there were any information asymmetry, it would be prominent when their perspectives are compared. Convenience sampling was used as participants were chosen based on availability and willingness to participate. Furthermore, the sample is from random sources which eliminates bias in responses. 
All participants are located in Dubai, United Arab Emirates except for 2 practitioners from Nigeria, 1 from Cyprus and 1 from Dundee, Scotland. The demographics of the participants are seen in the Tables 2 and 3.

The professors in this study are highly qualified and well experienced. They all have recognized professional qualifications and majority have Doctorate Degrees. The practitioners included individuals from various ages ranging from under 25 to over 40. Most of the interviewees have less than 5 years' experience. This is beneficial for this research because it concentrates on graduates who are just venturing into the professional world.

Document analysis, which involves interpreting documents was carried out using the learning materials and tasks that are given to the students in form of lectures, coursework and assignments. Past examination questions were also be inspected (Bowen, 2009). Document analysis is not a single method as it is used alongside other methods, so the insights data derived from it was used to support data extracted from the interviews (Bowen, 2009).

\section{Results and discussions}

\subsection{Interviews with professors}

As mentioned earlier, 5 accounting professors were interviewed. The questions asked revolved around discovering the level of understanding professors have on Big Data, whether they had appropriate knowledge on how it is being applied in workplace. The requirements they think are expected of their students. And their views on the including BD into the accounting curriculum. The interviews were used to develop codes which transformed into themes. The main themes extracted are discussed below.

Table 2: Professor Demographics

\begin{tabular}{|c|c|c|c|c|c|c|}
\hline Participants & Age & Sex & Qualification & $\begin{array}{l}\text { Highest } \\
\text { Educational } \\
\text { Qualification }\end{array}$ & $\begin{array}{l}\text { Place of } \\
\text { Work/Position }\end{array}$ & $\begin{array}{l}\text { Work } \\
\text { Experience }\end{array}$ \\
\hline L1 & $\begin{array}{l}40- \\
51\end{array}$ & M & CPA & $\begin{array}{l}\text { Doctorate } \\
\text { Degree }\end{array}$ & $\begin{array}{l}\text { University, } \\
\text { Professor }\end{array}$ & Under 5yrs \\
\hline L2 & $\begin{array}{l}\text { Over } \\
50\end{array}$ & M & CPA & $\begin{array}{l}\text { Master's } \\
\text { degree }\end{array}$ & $\begin{array}{l}\text { University, } \\
\text { Professor }\end{array}$ & Over 30 yrs. \\
\hline L3 & $\begin{array}{l}\text { Over } \\
50\end{array}$ & $\mathrm{~F}$ & $\begin{array}{l}\text { ACCA } \\
\text { Affiliate, CPA }\end{array}$ & $\begin{array}{l}\text { Doctorate, } \\
\text { Degree }\end{array}$ & $\begin{array}{l}\text { University, } \\
\text { Professor }\end{array}$ & Over 30 yrs. \\
\hline L4 & $\begin{array}{l}40- \\
51\end{array}$ & $\mathrm{~F}$ & - & $\begin{array}{l}\text { Doctorate } \\
\text { Degree }\end{array}$ & $\begin{array}{l}\text { University, } \\
\text { Professor }\end{array}$ & Over 15 yrs. \\
\hline L5 & - & M & CPA & $\begin{array}{l}\text { Doctorate } \\
\text { Degree }\end{array}$ & $\begin{array}{l}\text { University, } \\
\text { Professor }\end{array}$ & Over15 yrs. \\
\hline
\end{tabular}


In order to respect the privacy of the participants, they will be referred to as L1, L2, L3, L4, and L5 throughout this section.

\subsubsection{Background Knowledge of Big Data}

All professors interviewed had seemingly adequate knowledge of what Big Data is. When asked what they understood by Big Data, Participant L2 described it as:

A lot of data which essentially forms the basis for any future predictions and modelling...not only can be analysed into fractions but very large volume of data can be collected and assimilated from various sources.

While Participant L4 said:

A lot of information that is available on the net that can be used for decision making... That a lot of it is done by computer... It's all about Big data in most markets. It's the key thing to understand new trends and taking your company to the next level.

Participants L2 and L3 went as far as providing examples of how big data is used in the airline industry to predict customer behavior and make recommendations based on past trends. This is consistent with Vasarhelyi et al. (2015) where Big data analytics is used to predict customer behavior and enhance customer relationship. L5 also referred to social media analysis and how BDA can be used in the stock market. With regards to how it is used in accounting, Participant L2 added that "It can be used for predicting human behavior, consumer behavior or future trends". Contrary to this, Participant L1 said that "For marketing I can understand how it can be used but for accounting I still don't understand".

\subsubsection{The curriculum and student capabilities}

When asked whether their institution included Big Data in its accounting curriculum Participant L3 responded by saying:

We are in the accounting and finance department and we need these courses but most of them are housed in mathematics and computer science department...in postgraduate level, they are taught courses like quantitative research methods and research in finance and students learn the techniques of dealing with data using sophisticated software such as EViews and SPSS Social Science.

Participant L5 mentioned that "The university is trying but our typical university curriculums are difficult to readjust". When asked about the ability of their students to handle big data in work place based on the accounting curriculum, all participants did not believe the students were capable. Participant L4 elaborated by saying: "My 
undergraduate students who just graduated, probably not because we don't teach them the use of technology, we teach them the concepts". Likewise, Participant L3 stated that:

Our students particularly are not taught any modules in It so they are not equipped and we hope that they can do some professional training on that afterwards ...they are taught to use Microsoft Excel and Nvivo in research, but our analytics has not been formally introduced except for those doing business degrees because we added a course called business consulting and analysis.

\subsubsection{Perspective on Big Data analytics requirements}

When asked BDA skills the participants thought employees require from graduates, all participants mentioned that they needed Information Technology (IT) skills. Participant L2 stated that:

Most importantly what they need is IT skills, not just IT skills but super special IT skills like artificial intelligence...some kind of special knowledge and understanding of how to capture data efficiently because getting data is one part but then getting data efficiently is now the new ball game.

5 of the participants mentioned that students should be well versed on software such as SPSS, Excel, Eviews and Nvivo.

\subsubsection{Thoughts on introduction of Big Data in the curriculum}

All participants think it is crucial to introduce BD to the accounting curriculum. Participant L3 provided a distinctive reason why it has not been introduced yet: Partly, our curriculum has been captured by professional bodies because there is this desire to give students maximum exemptions, yet the professional bodies are not leading in the changes in analytics...that somehow has restricted our freedom as a university to expand the curriculum as we wish.

All participants provided suggestions on how it should be introduced into the curriculum. Participant L3, L1 and L5 stated that:

To begin with people should have a separate course in order for them to have a broad idea of what big data is then they can see its application in different fields.

For the time being I think some workshop seminars should be available to our students and until we have very solid literature on this...we can also incorporate existing modules such as accounting and information systems for now before we get proper literature for a course on Big Data. 
It might be more sensible to have a dedicated course, secondly for other courses such as auditing and financial accounting there should be some component linking them to big data.

A separate course is preferable for better understanding because Big Data analytics carries a lot of weight. Only Participant L4 suggested that "we can introduce it in existing courses and one or two lab sessions, not necessarily a separate course".

Plans on introducing big data to the curriculum are uncertain. Participant L3 specified that:

Yes. As the academic head of accounting I started by looking at what Russel Group universities are doing that is the top 24 in the UK and looked at their syllabi with the aim to see whether they are embracing technology and unfortunately only 4 of them are already teaching something in this area. However, they have optional courses which are valuable to students. Others are teaching it during summer school, so we hope we will come up with something similar.

All other participants were uncertain of whether it will be introduced to the accounting curriculum or not.

\subsection{Interview with practitioners}

Highly qualified accounting professionals working in accounting and auditing firms were interviewed. The interviews included 10 practitioners who were asked in depth questions about Big Data and its application in work place.

Table 3: Practitioner demographics

\begin{tabular}{|c|c|c|c|c|c|c|}
\hline Participants & Age & Gender & $\begin{array}{l}\text { Professional } \\
\text { Qualification }\end{array}$ & $\begin{array}{c}\text { Highest } \\
\text { Educational } \\
\text { Qualification }\end{array}$ & $\begin{array}{c}\text { Place of } \\
\text { work/position }\end{array}$ & $\begin{array}{c}\text { Work } \\
\text { Experience }\end{array}$ \\
\hline P1 & $41-50$ & M & Yes & $\begin{array}{l}\text { Doctorate } \\
\text { Degree }\end{array}$ & $\begin{array}{l}\text { University } \\
\text { Research, } \\
\text { Academic }\end{array}$ & Over 15 yrs. \\
\hline $\mathrm{P} 2$ & $\begin{array}{l}\text { Under } \\
25\end{array}$ & M & No & $\begin{array}{l}\text { Bachelor's } \\
\text { Degree }\end{array}$ & Company/Preparer & Under 5 yrs. \\
\hline P3 & $26-30$ & M & Yes, ACCA & $\begin{array}{l}\text { Master's } \\
\text { Degree }\end{array}$ & $\begin{array}{l}\text { University } \\
\text { Research, } \\
\text { Academic }\end{array}$ & Under 5 yrs. \\
\hline P4 & $\begin{array}{l}\text { Under } \\
25\end{array}$ & $\mathrm{~F}$ & Yes & $\begin{array}{l}\text { Bachelor } \\
\text { Degree }\end{array}$ & Company, Preparer & Under 5 yrs. \\
\hline P5 & $41-50$ & M & Yes & $\begin{array}{l}\text { Bachelor } \\
\text { Degree }\end{array}$ & Company, Preparer & Over 15 yrs. \\
\hline P6 & $26-30$ & M & No & $\begin{array}{l}\text { Master's } \\
\text { Degree }\end{array}$ & Regulator & Under 5 yrs. \\
\hline
\end{tabular}

Vol. 18, No. 3 


\begin{tabular}{|c|c|c|c|c|c|c|}
\hline Participants & Age & Gender & $\begin{array}{l}\text { Professional } \\
\text { Qualification }\end{array}$ & $\begin{array}{c}\text { Highest } \\
\text { Educational } \\
\text { Qualification }\end{array}$ & $\begin{array}{c}\text { Place of } \\
\text { work/position }\end{array}$ & $\begin{array}{c}\text { Work } \\
\text { Experience }\end{array}$ \\
\hline P7 & $\begin{array}{l}\text { Under } \\
25\end{array}$ & $\mathrm{~F}$ & Yes, ACCA & $\begin{array}{l}\text { Bachelors, } \\
\text { Currently } \\
\text { doing Masters }\end{array}$ & Audit firm, Big 4 & Under 5 yrs. \\
\hline P8 & $\begin{array}{l}\text { Under } \\
25\end{array}$ & $\mathrm{~F}$ & Yes, CPA & $\begin{array}{l}\text { Bachelor's } \\
\text { Degree }\end{array}$ & Audit Firm, Big 4 & Under 5yrs \\
\hline P9 & $\begin{array}{l}\text { Under } \\
25\end{array}$ & $\mathrm{~F}$ & $\begin{array}{l}\text { Yes, ACCA, } \\
\text { CIA }\end{array}$ & $\begin{array}{l}\text { Bachelor's } \\
\text { Degree }\end{array}$ & Audit Firm, Big 4 & Under 5 yrs. \\
\hline $\mathrm{P} 10$ & $41-50$ & $\mathrm{M}$ & ACCA & $\begin{array}{l}\text { Doctorate } \\
\text { Degree }\end{array}$ & Company, Preparer & Under 10yrs \\
\hline
\end{tabular}

In order to respect the privacy of the participants, they will be referred to as P1 ...P10 throughout this research.

\subsubsection{Use of Big Data in institution}

7 of the 10 practitioners interviewed have started using Big Data in their various institutions except Participants P1, P4 and P6. When asked in what aspects they applied BDA Participant P9, P4, P5 and P8 responses were:

So, for us for fraud because were into audit, so for frand we have this software for audit which basically helps us pic out our samples which have the highest risk of fraud so basically less manual intervention and more automatic.

The consulting part of our firm. Apart from auditing, we also provide consulting services to our clients, so we save and analyse all of their data into our software and make it available into everyone in our organisation.

Used for new investments.

When there is a huge company where they have a lot of transactions and a lot of entries what we do is use something called Journal voucher testing which completely automated using a software.

When asked forms of data used P9 stated that: "[i]t could be emails and excel data and journal entries", while P7 said that "past records and over the years newspapers, articles, our emails and client emails...we don't trust social media a lot". P8 disclosed that "the only thing we would actually be using are emails and sometimes videos". Big Data used by participants is seen to be more common in Text form. Participants P1, P4 and P6 who claim to not use Big Data also use data in text forms and emails.

\subsubsection{Competency of accounting graduates}

Participants were asked about accounting graduates performance using Big Data Analytics and they all mentioned that it is not easy for accounting students to handle 
big data. P8 mentioned that "It is actually very hard because you don't get to do it in university or before graduating because it focuses more on the theoretical aspect than practical".

They mentioned that training has to be provided for accounting employees to be able to handle Big Data. P8 stated that: "We get a lot of trainings during the year...the IT and risk assurance people get trained very well before they can deal with this". Similarly, P7 said: "It is not easy. But we have all gone through ample amount of training hours and we also have hired engineers who have done both accounting and engineering to give us trainings". Despite trainings, participants have mentioned that performance does not immediately improve. P9 states that "You learn mostly on the job".

\subsubsection{Skills, software and techniques needed}

When asked competencies needed, all participants mentioned that students should possess good decision-making skills. P8 mentioned that:

Human intuition and use of professional judgement, so someone who has a good theoretical background but at the same time knows how to apply this in real life and definitely good decision-making skills.

On Software used, P9, P5, P7, P8 and P10 stated that:

We have audit software so that compensates data and makes it easier and simpler for people to interpret data. The audit software is called Aura. (P9)

Software used is daceasy. (P5)

We have hired engineers with completed MBA's so they run statistics and back in work on computing software. They develop software. I've seen a lot of projects in which they've developed software for analysing data. (P7)

JV CATS. It is a complete system that you put in a company's trial balance and everything and it automatically does the test so that you can ensure that for example you can set it to detect any transaction and it does it on its own. Or you put in a keyword or errors and mistakes and it gets it on its own. (P8)

Students need to be well versed with software of big data such as $S Q L$ and tableau. (P10)

When asked about techniques used, Participants P9, P7 and P8 mentioned predictive analytics. Only Participant P2 mentioned prescriptive analytics. Participant P7 mentioned that "When asked to predict the future and what possibilities could be in that case we come into consensus with the client on what the probability is we agree on a probability and do an analysis on that".

\subsubsection{Thoughts on the accounting curriculum}

With regards to the absence of Big Data in the accounting curriculum, Participant P9 expressed that: "This is really a drawback I believe with large number of local and 
international universities. Should have incorporated data analytics into accounting curriculum". Similarly, Participant P7 expressed that:

Most of the universities are more theoretical than practical so a suggestion would be to have those students before graduating in contact with Big data specialist and maybe internships will help so they have an idea.

With regards to the inclusion of Big Data Analytics in the accounting curriculum, P7 and P10 stated that:

It is very helpful. I would highly recommend that because most of the organizations have started adopting big data and if it is not included in the curriculum it is not going to help them (students) so they'll need to go through extra training hours. so it is better to include it in the curriculum and give hands on experience. (P7)

I believe there should be a theoretical and practical course included in marketing, accounting and other fields in universities. (P10)

To emphasize the importance, Participant P10 mentioned that "I myself am a digital marketing specialist. However, I have decided to take a second master's in data science to make sure I stay ahead of the curve in this growing market".

\subsection{Document analysis on the accounting curriculum}

Accounting curriculums from 5 top Dubai universities were studied, and it was found that it contained strictly theoretical aspects of accounting. The courses included strictly manual calculations using tables and theoretical knowledge in courses such as management accounting, financial accounting and auditing. There is barely any use of software, analytical techniques and computers. Students are taught simple analytics courses such as quantitative methods, information systems in accounting and quantitative approaches to decision making. These courses include use of distribution tables, linear regression and simple tests and data used is in small quantity. Simple software such excel, SPSS and Nvivo are used for such calculations. Furthermore, these simple analytics are not critically taught, and students only use them when carrying out final year research projects.

\subsection{Discussion}

All professors interviewed had an adequate understanding of the concept of Big Data and Big Data Analytics. Most of them however did not provide in depth explanation of its uses, but they are all aware that it is used for predictive analysis and decision making. This is consistent with the findings of Gamage (2016). Only Participant L2 and L3 provided an explanation with reference to how customer analytics are used in the airline industry to provide recommendations for customers. Similarly, it is mentioned in the literature that customer analytics is used to improve customer relationship management. 
When asked if their various university accounting curriculums included Big Data, they all said no. Some participants mentioned that the universities do offer BDA courses and workshops but not for accounting students. Due to this, all professors assume their students cannot handle BDA because they strictly taught the concepts of accounting and barely any use of technology. Students are taught simple analytics courses and the use of simple software such as Statistical Package for the Social Sciences (SPSS), Excel, Eviews and Nvivo. Based on the document analysis, students are barely examined these.

When asked about competencies they thought are needed for BDA, all professors mentioned IT skills but were not specific. Participant L2 however stressed that nonconventional IT skills as well.

Participants are well aware of the importance of BD in accounting organisations and suggested that it should promptly be included in the accounting curriculum. All participants but one suggested that it should be introduced as a separate course. In later stages, it can be introduced in existing accounting courses such as management accounting so that students can see how it is applied in various aspects of accounting. Gamage (2016) provides a suggestion of how BDA can be included in various aspects of the accounting curriculum (See Appendix 1). Similarly, this was also suggested by Sledgianowski et al. (2017), and Pan and Tan (2017). Temporary solutions were suggested by them before proper literature is developed to make it a course. The suggestions include online courses and summer schools on BD. Furthermore, seminars and workshops can be held by BD engineers or professionals to explain the concepts to them. For schools that have analytics courses in other departments, it should be extended to accounting students.

Plans of introducing BD in universities were uncertain. Participant L3 distinctively noted that professional bodies such as ACCA and CPA are restricting the need to do so by not taking the lead and introducing BDA courses. Accounting students choose curriculums with exemptions so if these bodies include it, certainly universities will follow.

8 out of the 10 practitioners have started using BDA in their various institutions. It is used to analyse client data, predict outcomes of new investments and possibilities, fraud detection and journal entry testing by gathering and tracking transactions. It is used to detect errors in company tables, trial balance etc. This is consistent with Rezaee (2017), Sledgianowski (2017) and Vasarhelyi (2015) studies where the uses of BDA in various types of accounting are described.

Most of the data used by these practitioners are texts in form of emails, transactions, journal entries, client data, newspaper and articles. The software they use include Aura for fraud detection, DacEasy for accounting tables and Journal Voucher cATS for journal entry testing. Some of the participants' companies have software specifically created for them by data engineers using modifications based on the company's activities. Most of them use predictive analysis to predict future 
outcomes, risks, possibilities which is consistent with Kleckner (2017). However, some are seen to use prescriptive tools.

The participants expressed that it is difficult for accounting students to handle BDA because university curriculums focus on the theoretical aspects of accounting rather than the practical. This was mentioned by Participant L4 (professor) as well. Training workshops are held all year round on BDA software and techniques in these companies. Despite training however, performance does not escalate immediately. It takes years of experience as they learn on the job which could lead to inefficiency in early years of jobs. If it were taught in universities, costs and time spent on training will be reduced.

Like the professors, practitioners expressed that it is a drawback that BDA is absent in the curriculum and it should be promptly included. Most organisations use BDA so accounting graduates knowing how to handle it will be very helpful. They suggested that students can have internships before graduation to see how it is applied in accounting jobs and BDA engineers can provide them with workshops before the university adopts it.

\section{Conclusions, limitations and further research}

The main aim of this research is to explore whether accounting curriculum in universities is capable of producing competent accounting graduates with the employment of Big Data Analytics in the profession. It was discovered that Big Data is not present in the accounting curriculum, so it deprives students of the muchneeded knowledge and skills of BD. This has led to accounting graduates being incompetent when it comes to BDA in the profession and they have to be trained immensely to be able to handle it. The accounting curriculum being more theoretical has hindered their use of computer and software in work place. Both accounting professors and practitioners think it should be involved in the curriculum urgently and have provided temporary solutions before the inclusion. They understand that it is an important part of accounting organisations nowadays. According to King (2014), there is a definite shift with regards to the skills required from graduates entering the market and despite technical knowledge being important, BDA skills are in demand now.

Based on the BDA competencies discovered through the literature review and interviews with, the below framework has been developed (Figure 5). 


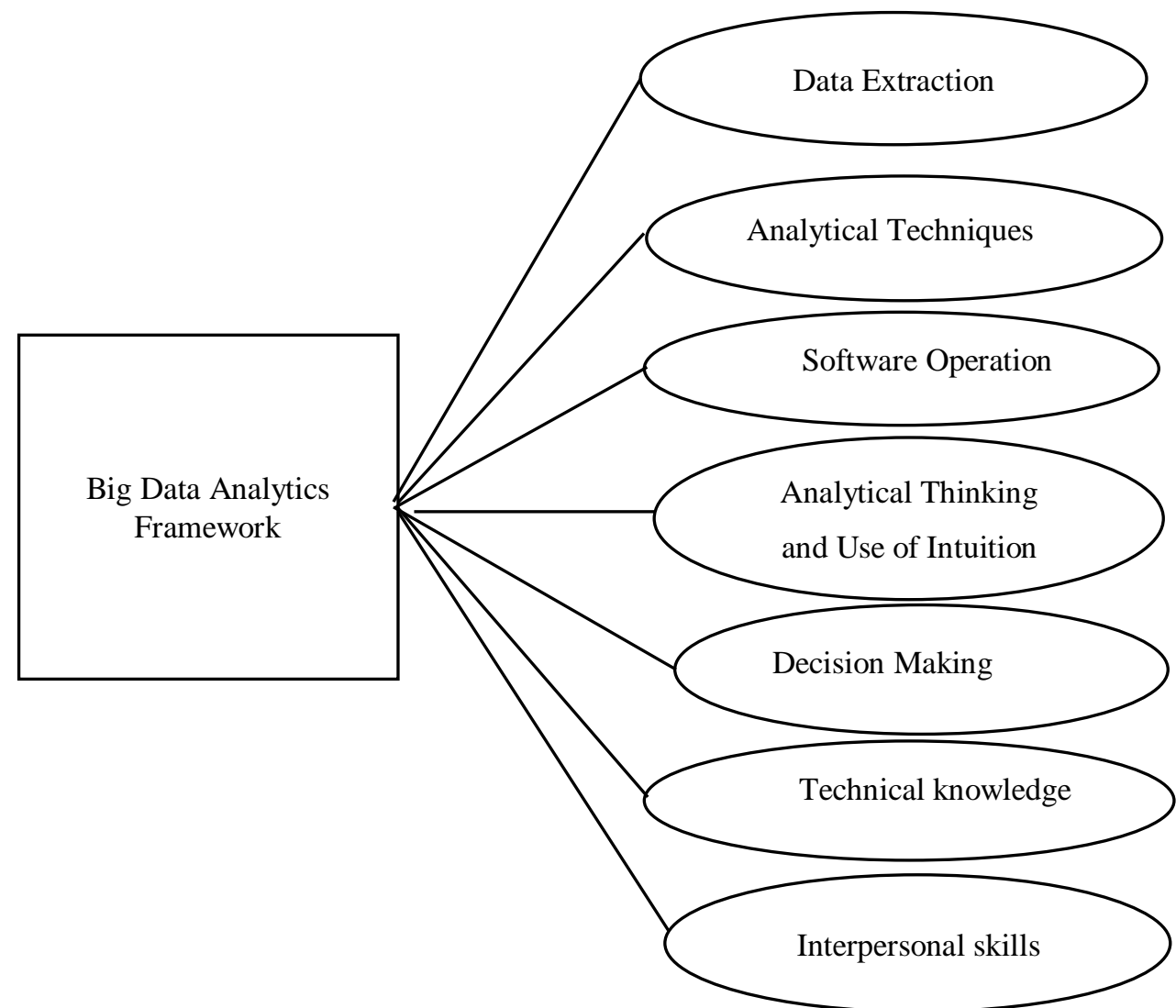

Figure 5: Framework showing competencies discovered from research

Accounting students should be able to extract potentially useful data in various forms from various sources to conduct analysis using techniques and software. Additionally, they should be able to use think analytically and their intuition to make decisions using insights from BDA. Furthermore, the basic concepts of BD should be taught to students for them to understand how to apply it proficiently in analytics. Lastly, Students should possess interpersonal skills such as problem-solving, technological skills, planning and organizing and self-management which will lead to efficiency in executing analysis.

Some universities and professional accounting bodies have considered BD in their syllabus. Chattered Institute of Management Accountants (CIMA) included a course titled Big Data in its syllabus in 2015. In the US, universities such as Rawls College of Business' school of accounting and Texas Tech University have incorporated BD in some of their courses. Furthermore, St. Mary's University's Greehey School of Business has formed a new programme called Accounting and Data Analytics (Chmielewski-Raimondo et al., 2016).

Even some emerging economies are following this trend. In 2015 Chartered Accountants Program of the Institute of Chartered Institute Accountants of Sri Lanka 
included Big Data in its curriculum. Malaysian Institute of Accountants and Ministry of Higher education have recognized the need to arraign accounting curriculum in line with developments in the profession. They called for inclusion of courses such as IT, system analysis and such to accounting programs (ACCA, 2019).

There are a number of additional areas for further research that were discovered during research. Particularly, this study needs to include more university and professional body accounting curriculums. This study used a diverse collection of practitioners, but more practitioners would be helpful in order to see a wider variety of how BDA is applied in various companies. This can be done using quantitative research as it is more convenient for a broad sample.

Furthermore, this study focused on Dubai alone. It would be beneficial to conduct study on a larger scale to avoid generelisation as a result of using a small sample. Lastly, in depth research could be done on what accounting practitioners are taught during training in various work places. This will aid in providing content that could be added to the curriculum.

This study adds to the limited literature on exploring the gap between the accounting curriculum and the practice due to the use of Big Data Analytics in accounting practices. Previous literature include research by Sledgianowski et al. (2017) and Rezaee (2017). Furthermore, it explores solutions to bridge this gap and provides a framework that can be utilized by university accounting curriculums and professional accounting bodies to equip students with the necessary competencies needed to handle Big Data. It will be of interest to accounting academics, practitioners, and professional accounting bodies.

Getting access to the auditors and accountants was difficult as they are always consumed in work. Some companies were emailed and called but there was no response. Additionally, some companies mentioned that their staff were not allowed to be interviewed. Professors from other Universities were also difficult to access. 5 professors were interviewed rather than the proposed 8. A few of the practitioners interviewed did not provide much information as expected. Furthermore, some participants had busy schedules, so the interviewing process had to stop till they were available. This slowed down research. Research mostly interviewed people in Dubai which could lead to a problem of generalisation as it was conducted on a small scale. This research has highlighted areas where further research will be beneficial. Areas where information was missing were highlighted in the literature review and later uncovered through research. However, during the course of this research, more areas that need research were discovered. The most important recommendation is to consider students' views. Additionally, quantitative research on this might be adopted in order to compare the results with qualitative ones. 


\section{References}

ACCA (2011) Big Data: Its Power and Perils [online], available: https://www.accaglobal.com/bigdata [accessed 18th January 2019]

ACCA (2019) Big Data [online], available: -https://www.accaglobal. com/my/en/student/exam-support-resources/professional-exams-studyresources/p5/technical-articles/big-data.html [accessed 18th January 2019]

Alsghaier, H., Akour, M., Shehabat, I., \& Aldiabat, S. (2017) "The importance of Big Data Analytics in business: A Case study", American Journal of Software Engineering and Applications, vol. 6(4): 111-115

Beattie, V. \& Pratt, K. (2003) "Issues concerning web-based business reporting: an analysis of the views of interested parties", British Accounting Review, vol. 35 (2): 155-187

Bhimani, A. and Willcocks, L., (2014) "Digitisation, 'Big Data' and the transformation of accounting information", Accounting and Business Research, vol. 44 (4): 469-490

Biu, B. \& Porter, B (2010) "The expectation-performance gap in accounting education: An exploratory study", Accounting Education: An International Journal, vol. 19 (1-2): 23-50

Bolt-lee, C., \& Foster, S. D. (2003) "The core competency framework: A new element in the continuing call for accounting education change in the United States", Accounting Education, vol. 12(1): 33-47

Borodo, S., Shamsuddin, S. M., \& Hasan, S. (2016) "Big data platforms and techniques", Indonesian Journal of Electrical Engineering and Computer Science, vol. 1(1): 191-200

Bowen, G. A, (2009) "Document analysis as a qualitative research method", Qualitative Research Journal, vol. 9(2): 27-40

Braganza, A., Brooks, L., Nepelski, D., Ali, M., \& Moro, R. (2017) "Resource management in big data initiatives: Processes and dynamic capabilities", Journal of Business Research, vol. 70, 328-337

Castellan, C. (2010) "Quantitative and qualitative research: A view for clarity" International Journal of Education, vol 2(2): 1- 14

Chapman, E. \& Young, J. (2010) "Generic competency rrameworks: A brief historical overview", Education Research and Perspectives, vol. 37 (1): 1-24

Chen, H., Chiang, R.H.L. and Storey, V.C., (2012) "Business intelligence and analytics: from Big Data to big impact", MIS Quarterly, vol. 36 (4): 1165-1188

Chmielewski-Raimondo, D. A., McKeown, W., \& Brooks, A. (2016) "The field as our classroom: Applications in a business-related setting", Journal of Accounting Education, vol. 34: 41-58

Collins, K. (2012) "Total profitability management: A powerful framework", Financial Executive, vol. 28(7): 58-61

Crowe, S., Cresswell, K., Robertson, A., Huby, G., Avery, A. and Sheikh, A. (2011) "The case study approach", BMC Medical Research Methodology, vol. 11(1): 100

Enget, K., Saucedo, G. D., \& Wright, N. S. (2017) “Mystery, Inc.: A big data case”, Journal of Accounting Education, vol. 38: 9-22 
Gamage, P. (2016) "Big Data: are accounting educators ready?", Journal of Accounting and Management Information Systems, vol. 15(3): 588-604

Hakim, C. (2016) "Are accounting graduates prepared for their careers? A comparison of employees' and employers' perceptions", Global Review of Accounting and Finance, vol. 7(2): 1-17

Hay, D. (2010) "The impact of globalization on professional accounting firms: Evidence from New Zealand", Accounting History, 15(3): 285-308

Janvrin, D. J., \& Weidenmier Watson, M. (2017) "Big Data": A new twist to accounting, Journal of Accounting Education, vol 38: 3-8

Kleckner, M., Ozgur, C. \& Li, Y (2015) "Selection of statistical software for solving big data problems: A guide for businesses, students and universities", Journal of Modern Applied Statistical Methods, vol. 16(1): 753-774

Lawson, R. A., Blocher, E. J., Brewer, P. C., Cokins, G., Sorensen, J. E., Stout, D. E., Sundem, G.E., Wolcott, S.K \& Wouters, M. J. F. (2014) "Focusing accounting curricula on students' long-run careers: Recommendations for an integrated competency-based framework for accounting education", Issues in Accouning Education, vol. 29(2): 295-317

Liu, Y. (2014). "Big data and predictive business analytics", The Journal of Business Forecasting, vol. 33: 40-42

McKinsey Global Institute (2011) "Big Data: The next frontier for innovation, Competition and Productivity", McKinsey Global Institute Report

Mohamed, E. \& Lashine, S. (2003) "Accounting knowledge and skills and the challenges of a global business environment", Managerial Finance, vol. 29 (7): $3-16$

Pan, G., \& Tan, G. H. (2017) "Designing an accounting analytics course using experiential learning approach designing an accounting analytics course", Accounting Business and the Public Interest, vol. 16: 1-23

Quek, A. (2005) "Learning for the workplace: a case study in graduate employees' generic competencies" Journal of Workplace Learning, vol. 17 (4): 231-242

Rezaee, Z (2017) "Relevance of Big Data to forensic accounting practice and education", Managerial Auditing Journal, vol. 34(3): 268-288

Sledgianowski, D., Gomaa, M., \& Tan, C. (2017) “Toward integration of Big Data, technology and information systems competencies into the accounting curriculum", Journal of Accounting Education, vol. 38: 81-93

Taylor-Sakyi, K. (2016) "Big Data: Understanding Big Data", Aston University, Birmingham, England

Vasarhelyi, M. A., Kogan, A., \& Tuttle, B. M. (2015) "Big data in accounting: An overview", Accounting Horizons, vol. 29(2): 381-396

Wamba, S. F., Gunasekaran, A., Akter, S., Ren, S. J. fan, Dubey, R., \& Childe, S. J. (2017) "Big data analytics and firm performance: Effects of dynamic capabilities", Journal of Business Research, vol. 70: 356-365

Warren, J., Moffitt, K. \& Byrnes, P. (2015) "How Big Data will change accounting", Accounting Horizons, vol. 29 (2): 397-407

Yin, R.K, (1984) Case study research: Design and method, Beverly Hills, Califormia: Sage Publications 


\section{Appendices}

\begin{tabular}{|c|c|}
\hline Course & Topics \\
\hline Business Statistics & $\begin{array}{l}\text { Data gathering techniques, Data exploration, Data } \\
\text { summarisation, Data analysis, Data visualization, } \\
\text { Communication of analytical findings }\end{array}$ \\
\hline Business Information & Advanced Databases, Information Retrieval, Advanced Data \\
\hline Systems & $\begin{array}{l}\text { Mining Applications, Predictive Analytics for Decision } \\
\text { Making, Big Data information management }\end{array}$ \\
\hline $\begin{array}{l}\text { Management } \\
\text { Accounting }\end{array}$ & $\begin{array}{l}\text { Application of Big Data to competitor analysis, Big Data as a } \\
\text { strategic resource }\end{array}$ \\
\hline Accounting & Business intelligence, Enterprise analytics Information search \\
\hline Information Systems & $\begin{array}{l}\text { and retrieval, Data mining, familiarity with languages such as } \\
\text { XBRL, specialized software/reporting systems with decision } \\
\text { support, ERP systems, Cybercrime, Data management issues }\end{array}$ \\
\hline Business Finance & $\begin{array}{l}\text { Financial analytics, modelling and computation of financial } \\
\text { risks, Information Risk Management }\end{array}$ \\
\hline $\begin{array}{l}\text { Auditing and } \\
\text { Assurance }\end{array}$ & $\begin{array}{l}\text { Data Analytics in auditing, Mine new sources of data, Data } \\
\text { integrity, Privacy, Safeguards, Cybersecurity, Design and } \\
\text { evaluate IS controls, Manage IS risks and compliance, } \\
\text { Overseeing fraud risk assessment }\end{array}$ \\
\hline Forensic Accounting & $\begin{array}{l}\text { Big Data, Benford's Law, Financial Analytics, Data Analytics } \\
\text { for Fraud, Anomaly Detection in Forensics and Security }\end{array}$ \\
\hline Taxation & $\begin{array}{l}\text { Indirect tax and Big Data, tax value and non- tax value form } \\
\text { data that is collected in the tax function, Visualize accounting } \\
\text { data }\end{array}$ \\
\hline
\end{tabular}

Source: (Gamage, 2016) 


\section{Appendix 2}

\section{Interview Questions for Professors}

Q1 Have you heard of Big Data?

Q2 What do you understand by it?

Q3 What do you think is required of accounting students by employees with regards to Big Data?

Q4 Do you think your students are well prepared for accounting jobs with the recent involvement of Big Data in the practice?

Q5 Are your students taught Big Data analytical skills and techniques? If yes, can you give examples of these skills and techniques?

Q6 Does your institution offer any specific course on Big Data Analytics? If yes what is the name of the course?

Q7 Are your students taught how to use any form of analytical software? If yes, please mention.

Q8 Does your institution have any future plans of introducing Big Data into its accounting curriculum?

Q9 What are your thoughts on introducing Big Data analytics to the accounting curriculum? Q10 What improvements do you think can be made to the curriculum towards this? (should a course on Big Data Analytics be introduced or should it be incorporated in existing courses)

\section{Appendix 3}

\section{Interview Questions for Practitioners}

Q1 Have you heard of Big Data and Big Data Analytics?

Q2 Has your institution started using Big Data Analytics? If yes, for how long?

Q3 In what aspects does your institution apply Big Data Analytics?

Q4 What form of Data do you mostly use? (eg images, emails, texts, audio, etc)

Q5 What techniques, skills and software do you use to analyse Big Data?

Q6 Are accounting graduates in your institution competent enough to handle Big Data Analytics or do they need further training? If yes, please mention type and length of training.

Q7 Do employees perform excellently after training?

Q8 What are your suggestions as to how the accounting curriculum can equip accounting students to be able to handle Big Data Analytics? 